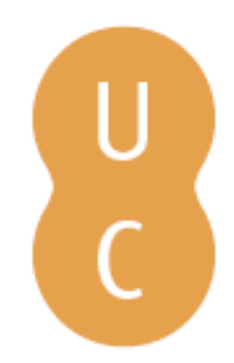

\title{
nombalina
}

\section{Establishing in criminal law the correlation between a traumatic event and a septal perforation of the nose a case study}

\author{
Autor(es): $\quad$ Carreira, C.; Sanches, R.; Costa, G. Santos; Vieira, D. N. \\ Publicado por: Imprensa da Universidade de Coimbra; International Academy of Legal \\ URL \\ persistente: \\ URI:http://hdl.handle.net/10316.2/31870 \\ DOI: \\ DOI:http://dx.doi.org/10.14195/978-989-26-0173-1_62 \\ Accessed : $\quad$ 26-Apr-2023 10:30:54
}

A navegação consulta e descarregamento dos títulos inseridos nas Bibliotecas Digitais UC Digitalis, UC Pombalina e UC Impactum, pressupõem a aceitação plena e sem reservas dos Termos e Condições de Uso destas Bibliotecas Digitais, disponíveis em https://digitalis.uc.pt/pt-pt/termos.

Conforme exposto nos referidos Termos e Condições de Uso, o descarregamento de títulos de acesso restrito requer uma licença válida de autorização devendo o utilizador aceder ao(s) documento(s) a partir de um endereço de IP da instituição detentora da supramencionada licença.

Ao utilizador é apenas permitido o descarregamento para uso pessoal, pelo que o emprego do(s) título(s) descarregado(s) para outro fim, designadamente comercial, carece de autorização do respetivo autor ou editor da obra.

Na medida em que todas as obras da UC Digitalis se encontram protegidas pelo Código do Direito de Autor e Direitos Conexos e demais legislação aplicável, toda a cópia, parcial ou total, deste documento, nos casos em que é legalmente admitida, deverá conter ou fazer-se acompanhar por este aviso.

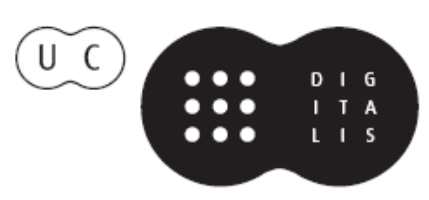




\section{Duarte Nuno Vieira Anthony Busuttil \\ Denis Cusack • Philip Beth}
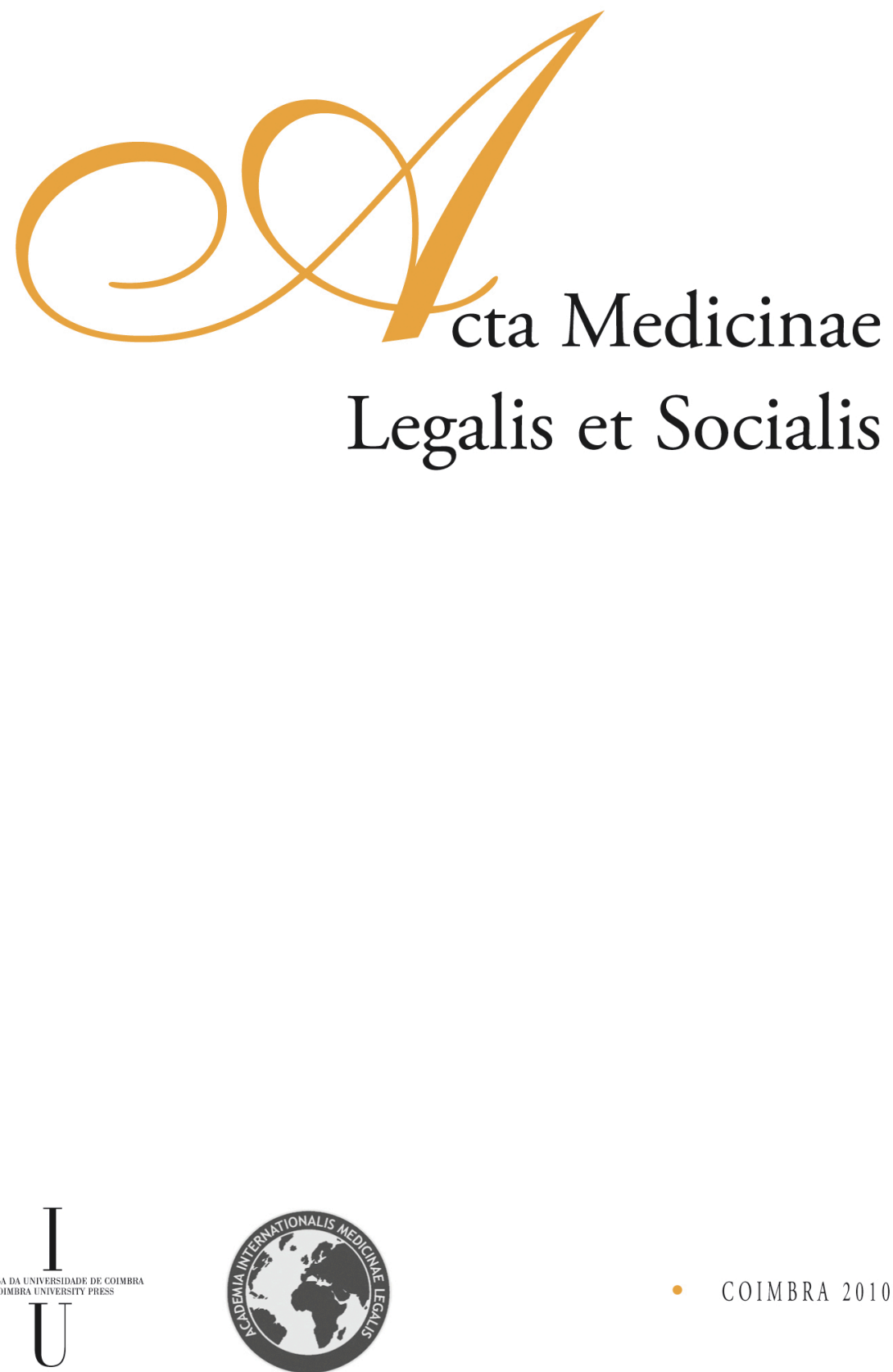
C. Carreira ${ }^{1,2}$, R. Sanches ${ }^{1}$, G. Santos Costa ${ }^{1}$, D. N. Vieira ${ }^{1,2}$

${ }^{1}$ Centre Branch of the Portuguese National Institute of Legal Medicine, Coimbra, Portugal

${ }^{2}$ Faculty of Medicine, University of Coimbra, Portugal

\title{
ESTABLISHING IN CRIMINAL LAW THE CORRELATION BETWEEN A TRAUMATIC EVENT AND A SEPTAL PERFORATION OF THE NOSE A CASE STUDY
}

\begin{abstract}
Septal perforation is a known complication following facial trauma. Despite being an uncommon aetiology, in the case study presented, the patient's information and clinical history seems to acknowledge it to be the only likely explanation, thus the particular interest of the following case discussion.
\end{abstract}

Introduction and objectives

The nasal septum is a structure composed of cartilage and bone, which separates the two nasal cavities. Its blood supply is assured by the overlying mucoperichondrium. When circulation is disrupted, perforation occurs.

There are many underlying causes for septal perforation, which can be classified into four main categories: Traumatic (most commonly self-induced from nose picking or resulting from facial trauma); Iatrogenic (surgical procedures and nasal intubation or nasogastric tube placement); Inhalation of irritants (such as cocaine, decongestive sprays, chromic or sulphuric acid fumes, glass dust, mercurials, phosphorous and others) and Inflammatory/Malignant causes (including tuberculosis, syphilis, Wegner granulomatosis and sarcoidosis), that should always be considered in the differential diagnosis. More specifically, the most common are: previous nose surgeries, cocaine use and chronic use of nasal steroid and decongestive sprays.

The aetiology of septal perforation is usually sex related and its determination is essential in establishing the treatment and prevention methods to be applied in each case.

Other important elements to be considered are characteristics such as the type and size of the perforation. Posterior perforations are typically asymptomatic and do not need any repair, whereas anterior ones commonly cause increasing crusting, recurrent epistaxis, nasal obstruction, whistling, malodorous discharge and saddle nose deformity (when the external nose collapses).

Treatment lies mainly in prevention in high risk patients, using local ointments, nasal emollients and estrogens, topical lavage and constant humidification. Surgically, different techniques can be used in accordance with the type and size of perforation, 
being the mucopericondrial bipediculed flap with cartilage interposition, the most used for any type of perforation and the one that has the best results.

As disclosed above, some aetiologies have obvious medico-legal implications, for example as in this case discussion, in the interpretation and differentiation of traumatic septal perforation.

\section{Case Study}

A 49 year old female, who reported falling in a bus and hitting her face on the seats ahead and floor of the vehicle. She referred immediate and abundant epistaxis and pain on her nose and right shoulder, breast and knee. She was observed at the location by an emergency team and then in a Hospital, where she was X-rayed. There were no apparent fractures, namely in the nose. There was also no active bleeding in the emergency room and thus, the patient was discharged.

One week later, the persistence and increase of pain, oedema of the nose, difficulty breathing and daily epistaxis led her to see an Otorhinolaringologist. She was submitted to an anterior rhinoscopy and diagnosed with a significant perforation of the cartilaginous septum.

Subsequently, one month after the accident, the patient was subjected to a CAT scan where it was possible to visualize a discontinuity of the cartilaginous septum of the nose measuring 33 millimetres horizontally and 15,5 millimetres vertically (Fig. 1 - 6). Given the large size of the perforation, the patient was informed that surgical reconstruction was not possible.

During the medico-legal examination, in the investigation of past medical history, she denied the use of any type of nasal sprays, inhalation of other irritant substances or the use of drugs such as cocaine. She also denied having been submitted to any previous nasal surgery or medical procedures such as cauterization, nasogastric tube placement, intubation and/or perinasal oxygenation. She also had no history of disease which could cause nasal perforation.

\section{Discussion and Conclusion}

It is well known that the cartilage of the septum relies upon the overlying mucoperichondrium for its blood supply and nutrients. Therefore, most traumatic perforations result from mucosal lacerations on corresponding sides of the septum with exposure of the underlying cartilage or from its fracture which impede the blood flow, ultimately leading to necrosis of the tissues and perforation.

In this specific case, although a rhinoscopy was promptly carried out by a qualified Otorhinolaringologist, merely one week following the alleged traumatic event, no comment was made concerning the state of the mucous membrane or of the margins of the perforation. This information would have been most helpful when determining the compatibility with an injury of recent traumatic origin. 
Despite not having this important macroscopic description and even though the patient was submitted to a CAT scan one month subsequent to the accident, conclusions could be drawn from the patients information reported during the medicolegal examination, as well as from the documentation referent to the patient's medical history sent by her general practitioner.

As a result, given the exclusion and/or lack of confirmation of all the most frequent causes of this lesion, already described above, one was left to admit to its traumatic aetiology and succeeding rapid evolution.

Accordingly, in this particular case, the medico-legal experts included the septal perforation presented, as having contributed to the increase of the period of temporary general incapacity, as well as of the period of incapacity for work. And although it was assessed as being a permanent consequence of the traumatic event described, it was also stated in the final report, that it was not a cause of severe disfiguration to the patient, nor did it severely impair her respiratory function.

\section{References}

BATISTA DE OLIVEIRA R.C. et al. Perfuração septal. Escolha da técnica cirúrgica, Acta ORL V.24 n.3:134-138, 2006.

BATNIJI R.K. and CHMIEL, J.F. Septal Perforation: Medical Aspects, http://emedicine. medscape.com/article/863325-overview, 2009.

DOSEN, L.K. and HAYE, R. Nasal septal perforation 1981-2005: Changes in etiology, gender and size, BMC Ear, Nose and Throat Disorders, 7:1,2007.

PENHA L. Otorrinolaringologia, Gráfica Antunes \& Amilcar, Lda 215-236, 1998.

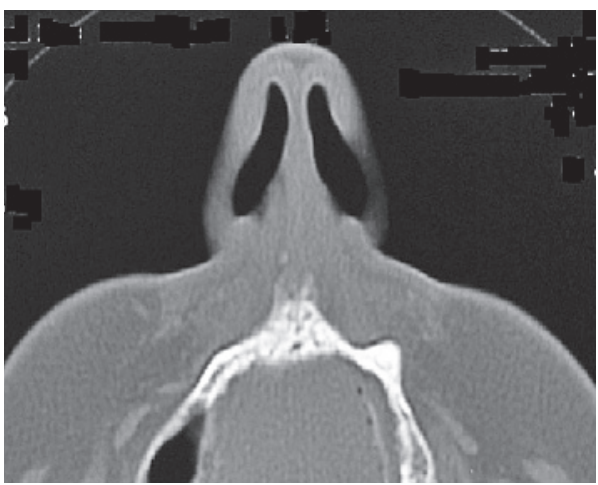

Figure 1 - First image from the CAT scan of the nose

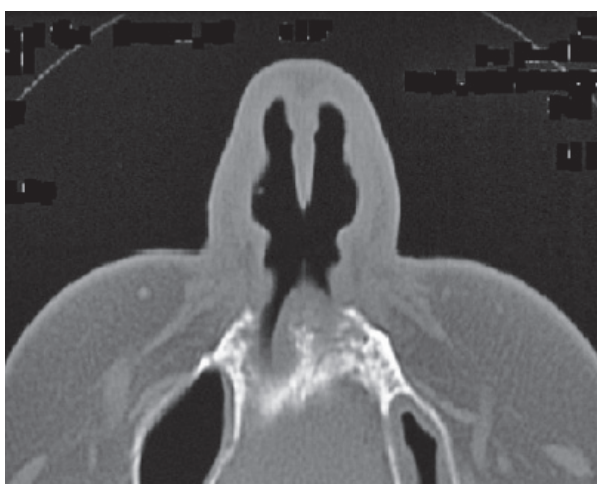

Figure 2 - Inferior aspect of the perforation of the septum 


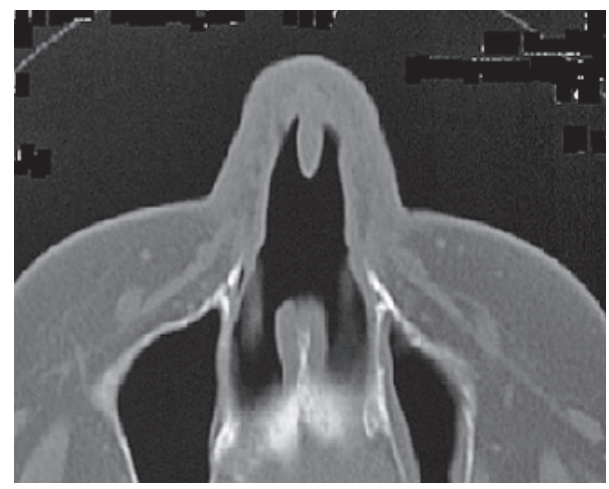

Figure 3 - Central part of the septal perforation

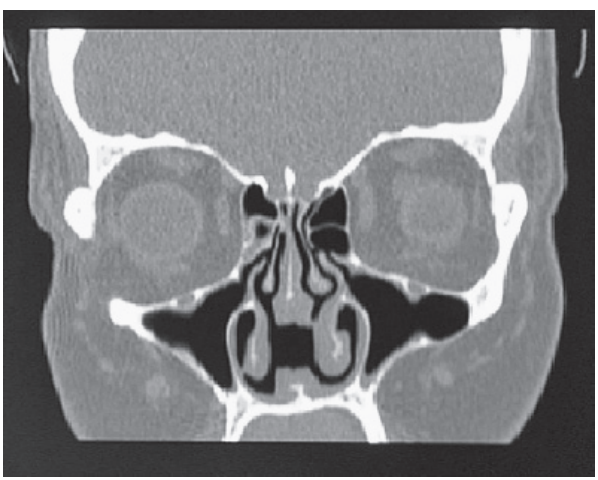

Figure 5 - Coronal view of the septal perforation of the nose

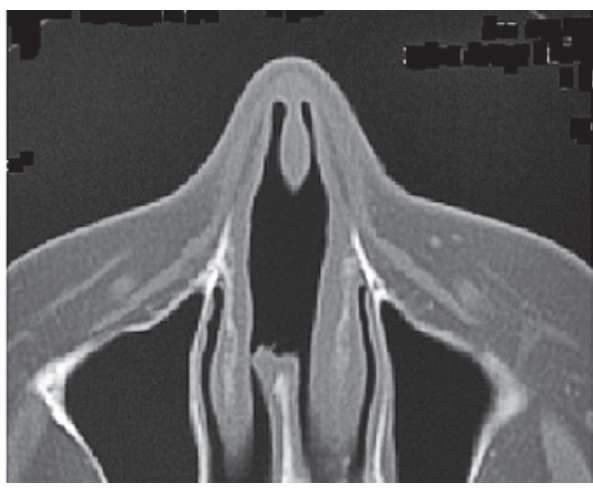

Figure 4 - Widest parte of the septal perforation

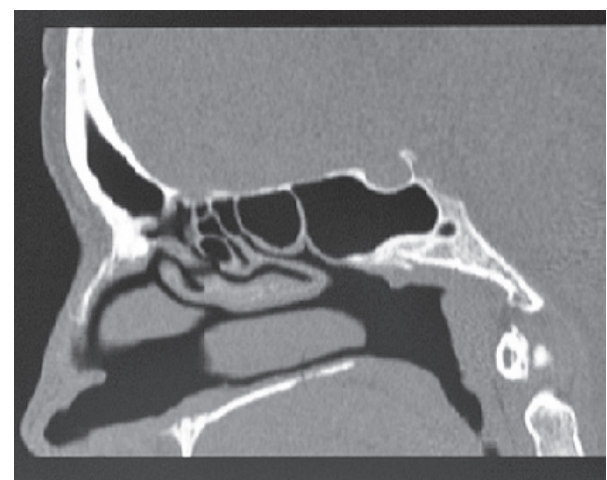

Figure 6 - Lateral view of the septal perforation of the nose 